DOI: $10.15276 / \mathrm{EJ} .01 .2020 .3$

DOI: $10.5281 /$ zenodo.3975501

UDC: 351.72

JEL: H54, O31, O38, Z18

\title{
KEY ASPECTS OF THE STATE INFLUENCE MECHANISM ON INVESTMENTS ATTRACTION BY LOCAL AUTORITIES
}

\section{КЛЮЧОВІ АСПЕКТИ МЕХАНІЗМУ ДЕРЖАВНОГО ВПЛИВУ НА ЗАЛУЧЕННЯ ІНВЕСТИЦІЙ ОРГАНАМИ МІСЦЕВОГО САМОВРЯДУВАННЯ}

\author{
Anzhela V. Kulinska, Doctor of Economics, Associate Professor \\ Odessa National Polytechnic University, Odessa, Ukraine \\ ORCID: 0000-0002-3609-3697 \\ Email: anzelakulinskaa@gmail.com \\ Irina R. Kravtsova \\ Odessa National Polytechnic University, Odessa, Ukraine \\ ORCID: 0000-0002-5405-3226 \\ Email:irina010699@gmail.com
}

Oleksandr S. Balan, Doctor of Economics, Professor Odessa National Polytechnic University, Odessa, Ukraine ORCID: 0000-0001-6711-5687

Email: shurabalan@ukr.net

Received 02.01.2020

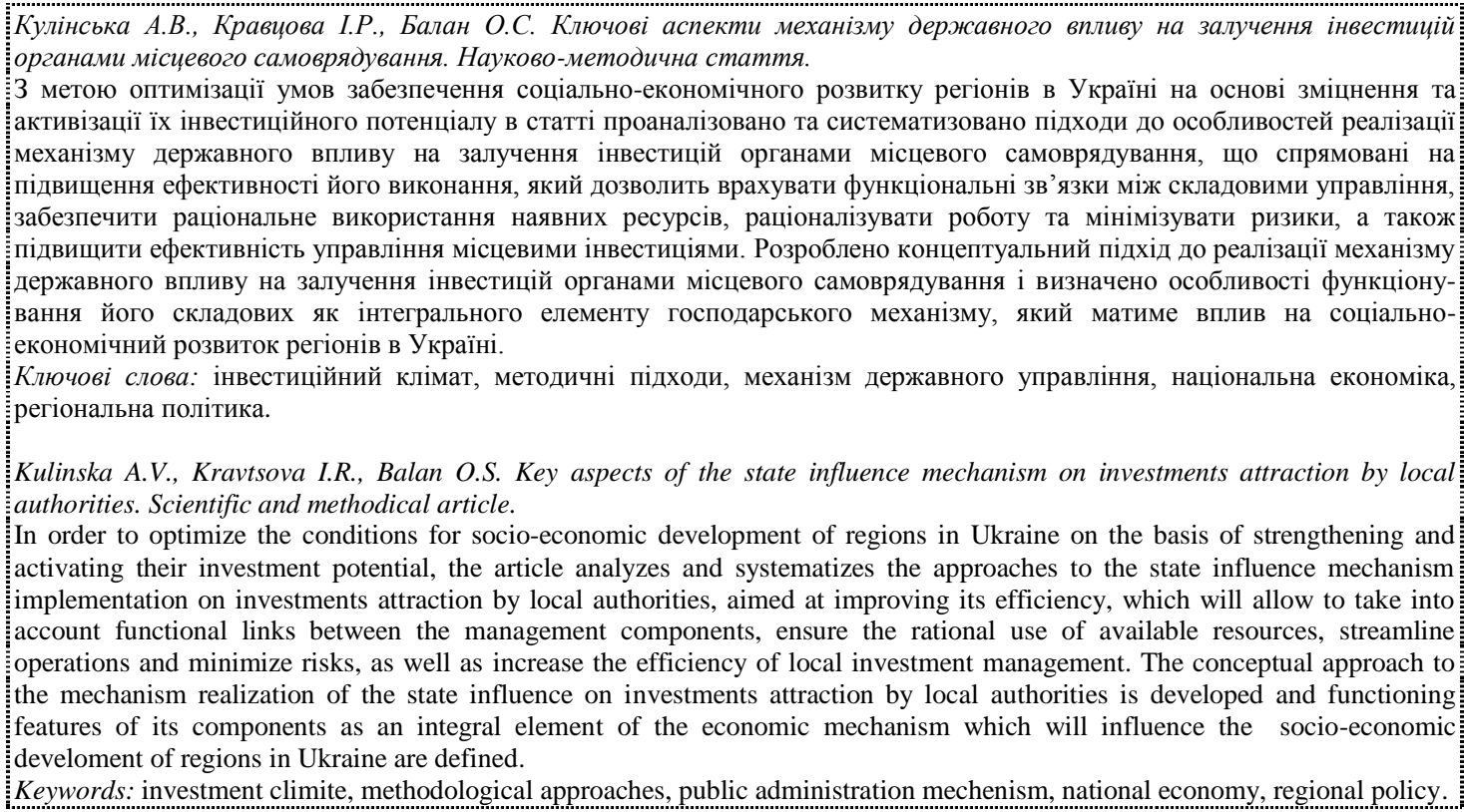

$t$ is obvious that the acute shortage of investment resources limits Ukrainian enterprises competitiveness and opportunities for their innovative development, as well as intensifies the complex of threats to the investment policy formation of regional development. Today, Ukrainian businesses operating in an unstable market environment are experiencing a deep decline in production and are in the critical condition or in the condition of bankruptcy. Therefore, the abovementioned indicates that against the general economic instability background there is a high probability of crisis emergence and development during economic activities, which necessitates the search for ways to improve the economic resources efficiency at the regional level, as one of the management approaches to influence the investments attraction by local authorities.

It requires to pay attention to the issues related to ensuring the liquidity and solvency of economic entities on the basis of the optimal combination of own or borrowed funds, making a profit and achieving an appropriate level of profitability sufficient to meet the needs of economic activity and its activation, studying the conditions creating a favourable investment climate in the regions and increasing their investment attractiveness level, 
attracting the investments resources and their effective use at all governmental levels through the implementation of the state influence mechanism on investments attraction by local authorities.

\section{Analysis of recent researches and publications}

The essence evaluation of this economic category suggests that the investment component in the structure of the state influence mechanism on the regional development policy formation of economic entities is poorly researched and studied by the concept of national economic science. Thus, these features of the mechanism implementation of state influence on investment attraction by local governments are reflected in the studies of such scientists as V. Bodrov [1], O. Havryliuk [2], O. Zakharov ta P. Pryhunov [3], V. Kyrylenko [4], S. Kozhemiakina [5], O. Makariuk [8], Yu. Skolotianyi ta O. Dubynskyi [9], V. Fedorenko [10], L. Chahovets [11] and others. However, in the scientific researches of these academic economists, this area study is limited mainly to economic relations at the macro level.

\section{Unsolved aspects of the problem}

The conducted studies identify several key approaches to understanding and addressing this issue, for example, according to some scholars $[1,4,7,11]$, the state influence mechanism on investments attraction by local authorities should be understood as the ability to maintain capital investment at the level which would guarantee the necessary pace of reproduction, restructuring and technological re-equipment of the economy, made it possible to combine the economic entitiesneeds in capital investment in terms of volume and structure, taking into account the efficient use and return of their resources.

Thus, V. Bodrov [1], V. Kyrylenko [4] and L. Chahovets [11] believe that the state influence mechanism on investments attraction by local authories involves the process of ensuring the condition of the national economy in which the economy is able to keep and maintain a sufficient leve of investment resources in the implications of internal or external threats, which is necessary for the socio-economic stability of the regions in Ukraine and the competitiveness growth of their economic entities. Bearing in mind the abovementioned, it can be argued that, on the one hand, the mechanism of state influence on investment attraction by local governments characterizes the level of use of investment resources in economic policy of economic entities, but, on the other hand, determines the process and directions of their effective use.

Regarding another approach to understanding the essence and solving the researched issue, some investment specialists, such as O. Havryliuk [2], S. Kozhemiakina [5], Yu. Skolotianyi and O. Dubynskyi [9], emphasize that the implementation of state influence mechanism on investments attraction by local authorities is the ratio level between the amount of domestic investment abroad and investment resources, which meets the needs of Ukraine's national economies and maintains the state's positive balance at the regional level. Thus, the peculiarities implementation of the state influence mechanism on investments attraction by local authorities should take into account the reduction of Ukrainian capital exports outside the country, a high degree of international capital, lack of large masses of free foreign capital and fierce competition between areas of its investing in Ukraine or countries, which attract foreign capital.

In our opinion, the discursive conceptual provisions of the state influence mechanism on investment attractions by local authorities in Ukraine indicate the need to generalize them in order to clarify the role of the investment component in the structure of the state influence mechanism on regional development policy of economic entities, that will allow to develop conceptual approach to identify its features of implementation as a structural and integral element of the economic mechanism, and will have an impact on the socio-economic development of regions in Ukraine, the algorithm of which is presented in the process of solving this scientific problem.

The aim of the article is to substantiate the theoretical and methodological provisions and practical proposals for the implementation of the state influence mechanism on investments attraction by local authorities as an integral element of the economic mechanism that will affect the socio-economic development of regions in Ukraine.

\section{The main part}

It is determined that the decisive role in the formation and implementation of the state influence mechanism on the development of regional investment policy in Ukraine and its economic entities belongs to the government's investment climate, which is a set of political, legal and economic conditions that provide and promote domestic and foreign investors' investment activity. Thus, O. Zakharov and P. Prygunov [3] note that the state should promote the formation of an attractive investment climate and guarantee foreign investors the inviolability of their fixed capital or the opportunity of its return with a profit.

Due to the importance of this component for the implementation of the state influence mechanism on investments attraction by local authorities a set of factors that determine the country's investment climate, ensure its further development and influence the investment process of economic entities or its activity in the state, because the significance of each factor depends on the level of economic development, historical and national trends are identified and grouped in the article (Fig. 1).

But a common problem to ensure the effective implementation of the state influence mechanism on investments attraction by local governments in the Ukraine's economy is that the state investment climate during 
the reforms is determined by the lack of its own investment resources, reduced long-term loans, high credit rates, and of capital investments reduction in various spheres or branches of the national economy.

It should be noted that the investment climate in Ukraine was very unfavourable, especially for foreign investors. Some "warming" in this regard occurred in 2008, when Ukraine began to develop and pursue of the accession policy to the World Trade Organization and possible membership in the European Union. Also, according to the United Nations, Ukraine was among the twenty most attractive countries for investors, ranking 18th in this list [8]. In addition, Ukraine is still attractive for investments, but it has not stayed away from global processes, because it is sufficiently integrated into the world economy, and the macrostability violation in foreign markets has its echo in internal processes in Ukraine.

Thus, according to the data of the leading organization of international business in Ukraine, the European Business Association [7], in evaluating the actual changes that have occurred in the the country's investment climate since the re-election of the President of Ukraine in 2014, investors differ: 56\% of businessmen dissatisfied with the investment climate in Ukraine, 24\% of managers did not notice positive changes, but $15 \%$ noted the national currency stabilization and 5\% noticed improvements at the macro level.

According to most domestic experts, such as V. Bodrov [1], O. Zakharov ta P. Pryhunov [3], V. Kyrylenko [4], S. Kozhemiakina [5], O. Makariuk [8] ta V. Fedorenko [10], a favourable regulatory framework for investment activities has already been created in Ukraine today. For example, the investment sphere is regulated by the Law of Ukraine "On Investment Activity" № 1560-12 of 18.09.1991, the Law of Ukraine "On the Foreign Investment Regime" № 93/96-VR of 19.03.1996, the Law of Ukraine "On Joint Investment Institutions ( mutual and corporate investment funds)" № 2299-14 of 15.03.2001, which provides a state guarantee of investments protection, regardless the ownership or investments sources, compensation for losses including lost profits or non-pecuniary damage caused to them as a result of measures, inaction and improper performance governmental bodies and official structures of statutory obligations to a foreign investor, investments return to the investor in kind or in foreign currency without paying duties, as well as income from these investments return in cash or in kind in case of termination of Ukraine's investment policy, application of national currency regime regulation and collection of taxes on the Ukraine's territory of to sub Business entities or other legal entities created with the participation of foreign investments, regardless of the form and time of their introduction, etc.

It is determined that in recent years Ukraine has successfully implemented a number of practical steps that have contributed to active integration into the world economic space and increasing the investment attractiveness of the regions: signed intergovernmental agreements on promotion and mutual protection of investments with more than 70 countries; 60 international agreements on avoidance of double taxation have been concluded with some countries of Europe, Asia, North and South America, Africa; it received the status of a member of the World Trade Organization and established the State Agency for Investment and Management of National Projects of Ukraine, which was liquidated in 2015.

It is substantiated that among the main reasons for the unattractiveness of the Ukrainian investment climate, academic economists $[2,5,8,10-11]$ emphasize the slow pace of reforming of both the national economy and the legal framework, difficult prerequisites for foreign investors to enter the Ukraine's regions, irrational distribution of domestic private or public investment, as well as the unfavourable investment climate in Ukraine can be explained by the inability of the state to provide financing for those economic entities that cannot be invested from private sources.

\begin{tabular}{|c|c|}
\hline \multicolumn{2}{|c|}{$\begin{array}{l}\text { tendencies and dynamics of market economy development } \\
\text { (transparency of privatization processes, inflation and its influence on investment activities, availability of free competition and target markets, } \\
\text { firmness of national currency, characteristics of the banking sector of the economy, the country's international rating, collaboration with } \\
\text { international financial institutions) } \\
\text { characteristics of the country's natural resource potential }\end{array}$} \\
\hline \multicolumn{2}{|c|}{ INVESTMENT CLIMATE } \\
\hline $\begin{array}{l}\text { INSTITUTIONAL FACTORS } \\
\text { organizational and legal cover funds/coverage } \\
\text { (availability of state institutions to support investment activities, } \\
\text { effective legal framework, the degree of state intervention in the } \\
\text { economy, transparent procedure for registration of companies with } \\
\text { foreign investments, effective judicial system) } \\
\text { political regime } \\
\text { (political situation in the country, the level of public confidence to the } \\
\text { government, the relationship between central executive bodies and local } \\
\text { officials) }\end{array}$ & $\begin{array}{l}\text { SOCIAL-PSYCHOLOGICAL FACTORS } \\
\text { (social changes and the level of society's social development, } \\
\text { observance of civil and human rights, the level of social tension, the } \\
\text { potential of social protest, the population's labour conditions, the level } \\
\text { of qualification training, availability of free labour resources ) }\end{array}$ \\
\hline
\end{tabular}

Fig. 1. The set of factors that provide the investment climate in Ukraine Source: authors' own development 
It is found out that private investors cannot invest in certain sectors of the country's national economy, and it is therefore necessary for the state government to establish stages of investment strategy in such a way, that there should be no substitute for private investment in the budget, as this reduces the investment level in the public influence mechanism on the development of regional policies and diverts reserves from important tasks, which the private sector cannot perform, i.e., the state needs to invest in those sectors of the national economy, that remain unattractive to private investors.

In order to assess the current state of the investment climate in Ukraine and its attractiveness for both investors who have already found themselves in this area, and for those who are just entering the Ukrainian economy, the article analyzes the dynamics of Ukraine's investment attractiveness index for 2014-2019, which was initiated and calculated by the European Business Association [7], as the arithmetical average of estimated values of five aspects of the state's investment climate. The analysis results of the dynamics of Ukraine's investment attractiveness index for 2014-2019 show that the index (2.57 on a 5-point scale) remains in a negative plane, because it is below 3 points (neutral value), which became the basis for determining and calculating the risk degree of the state influence mechanism on investments attraction by local authorities and the possibility of its use in the implementation of public administration in the national economy under pressure from the tax system, corruption, lack of reforms in this area or positive changes that will be presented in the research.

Taking into account the circumstances identified during the evaluation of the current situation in the context of financial restructuring of the market economy, it has been found out that the development and implementation of the state influence mechanism on investments attravtion by local authorities in Ukraine is impossible without the next structural element, such as investment in or abroad through the country's stock market, because it is through the stock market mechanisms the supply or demand for investment resources are formed, their accumulation or redistribution for economic growth, ie there is a movement of capital through the circulation of various securities and their derivatives.

According to the data of the National Commission on Securities and Stock Market [6], in 2019 the volume of trades on the securities market with the participation of non-residents amounted to 345.12 billion UAH. Thus, the interest of foreign investors in Ukrainian assets in 2019 increased by only $0.27 \%$ compared to 2018 . In recent years, the sales volume of securities by non-residents exceeds the purchases volume. In 2019, the transactions volume for the securitiessale by non-residents increased by $5.83 \%$ compared to 2018 .

Thus, in 2019 there is a capital outflow of foreign investors from Ukraine's stock market: the balance of trade activities with non-residents in the annual total amounted to -22.78 billion UAH. Foreign investors withdrew capital from Ukraine's stock market, selling shares, the balance was -20.70 billion UAH. In 2019 the positive growth was due to a slight increase in the purchase of investment certificates, the balance amounted to 1.01 billion UAH. As for the structure of the attracted investments volume with the participation of non-residents with distribution by countries, the largest volume belonged to such a country as Cyprus, whose annual balance amounted to +14.18 billion UAH.

At the same time, in recent years there has been a tendency to increase the nominal value of securities owned by non-resident owners. According to depository institutions [9], as of the end of 2019, the total nominal value of securities owned by securities holders amounted to 887.69 billion UAH, including the nominal value of securities owned by non-resident owners, amounted to 242.92 billion UAH. Thus, the growth rate of the securities nominal value owned by non-resident owners in 2014-2019 ranged from $99.76 \%$ to $138.64 \%$. Thus, the largest nominal value of securities of non-resident owners who owned significant share units in issuers $(10 \%$ or more of the company's capital), as of the end of 2019, was recorded among representatives of countries such as Cyprus (18.68\%), Russia (9.66\%), the Netherlands (5.94\%).

As it can be seen, such a scale of foreign investors' capital is only a small part of the real needs of Ukraine's national economy, and these needs are estimated by some experts [4, 9] at 100-150 billion USD, because the capital investments attraction, first of all, requires the following sectors of the national economy, such as domestic metallurgy, mechanical engineering, transport, chemical and oil and gas industries.

In particular, according to S.M. Kozhemiakina [5], nowadays it is said a lot about the potential of regions development in Ukraine and about the countless profits that can be obtained by investors, but the specialist emphasizes that it is necessary to look at the realities: investment needs are still technological and are not yet economic. It is well known that this type of expenditure is non-recoverable, so if the efficiency of economic investment at all governmental levels is considered, as is the rate of return on investment, it is obvious that efficiency will be assessed, no efficiency will be considered at all.

Also, O.V. Havryliuk [2] and O.V. Makariuk [8] draw attention to the western investors's low activity and their interest in investing in the Ukraine's regions. Even those investors who operate in the Ukrainian market say that they are not satisfied with the investment return. Foreign investors express dissatisfaction with the confusing legal framework with which they have to have conflicts and the payback period of capital that exists, because in Ukrainian conditions the return can be expected on average with a positive outcome in 5-8 years, while in other countries this period is 2-3 years.

Summarizing the abovementioned, it is determined that the main source of ensuring the implementation of the state influence mechanism on investments attraction by local authorities in the system of public administration of Ukraine's national economy are own resources of economic entities, but successful integration into the economy of regional development as the loss of working capital or depreciation funds and their 
withdrawal from businesses in the state budget for purposes incompatible with investment, the tax system in the country collects from legal entities and individuals huge taxes on the maintenance of the state apparatus or its services, lack of investment insurance system, the widespread practice of providing short-term loans at high interest rates, as banking institutions provide almost no long-term loans, as well as the securities attractiveness in the stock market of Ukraine is very low due to the expected decline in the national currency, this applies primarily to domestic government loan bonds and conversion discount bonds.

The effectiveness of the implementation or use of the proposed mechanism of state influence in ensuring the regional investment policy development in Ukraine and its key structural elements as one of the ways to increase its effectiveness at the national level can be assessed using the indicators system, the list of which and recommendations was approved by Ministry of Economic Development and Trade of Ukraine "On Approval of Guidelines for Calculating the Level of Economic Security of Ukraine" № 1277 of 29.10.2013 [10].

However, monitoring the indicators names, their measurement units, the order of calculation of indicators and input information sources allow us to conclude that the main task of the indicator system, which determines the level of investment potential of the national economy and its entities, is to assess the impact of identified threats security on its objects vulnerability, determining the level of management decisions quality, early warning of the dangerous phenomena approximation and preventive measures to avoid or reduce the negative consequences of their actions.

It is revealed that the evaluating method of the current level of implementation of the state influence mechanism on the investment policy formation of regional development and its economic entities and calculating the dynamics of the identified factors on the structural elements of its provision mechanism is weak, and the practice of their evaluation does not differ in the variety of means, as the indicators considered are not unambiguous interpretations, rather than statistical indicators, cannot be assessed over time or be suitable for showing the direction of change in the activities of the entities, do not reflect objectively existing and relevant possibility of negative impact on the entities providing for it, which increases the importance of measuring the reliability of expected and estimated results.

Having analyzed the stages and features of the state influence mechanism on the investment policy formation of the national economy regional development and its economic entities as an integral element of the economic mechanism that has an impact on socio-economic development of regions in Ukraine, the article examines the scientific investigations of leading experts such as V. Bodrov [1], V. Kyrylenko [4], Yu. Skolotianyi, O. Dubynskyi [9] and V. Fedorenko [10] in order to identify, systematize and implement measures to reduce the consequences of threats to Ukraine's regional investment policy, which can lead not only to the deterioration of not quite so very attractive investment climate of the state, reducing the dynamics of the index of investment attractiveness and investments movement in Ukraine or abroad through the securities market, and also challenge thepriority areas implementation of public policy regarding the market infrastructure improvement of Ukraine's stock market, as it is one of the conceptual provisions of public administration system of the national economy (Fig. 2).

\section{INVESTMENT POLICY OF REGIONAL DEVELOPMENT}

\section{POLITICAL INSTABILITY}

frequent change of the country's government, promises to change the political course, business climate up to the nationalization of investors'

property, which is heard by various political forces, especially in the pre-election period, which, in turn, increases foreign investors' vigilance and is perceived by them as additional risks that require return on investment.

\section{LEGISLATION DISADVANTAGES IN THE INVESTMENT AREA}

This threat has led to the exit of many investment companies from the Ukrainian market, which have already adapted to the game rules in an imperfect regulatory field, but could not assume that this process would take long and manifest itself in the absence of business inspections system,

long-term procedure of registration and obtaining the necessary certificates, ambiguous interpretation by various governmental branches of constantly changing legislation, imperfect system of cases consideration in commercial courts and untimely execution of their decisions, lack of an effective mechanism for protecting investors from debtors or dishonest partners.

\section{THE STATE'S EXCESSIVE FISCAL ACTIVITIES}

a powerful lever to curb investment in Ukraine is the extremely unfavorable distribution of tax pressure, which is excessive for legally operating businesses against the existence background of a huge "shadow" sector of the economy. Despite the fact that the extraordinary majority of foreign investors try to conduct transparent and legal business, the «shadowing» of the economy significantly complicates their cooperation with domestic enterprises, which are not always able to afford the risk of transparent or legal transactions. One of the most urgent is the issue of timely refund of previously paid VAT by the tax authorities, multi-level income tax, instability of tax rates and rules for their calculation.

\section{THE STATE'S ONEROUS CUSTOMS POLICY}

investors pay their attention to high duty rates on imports of foreign investment in the country, misunderstandings with customs authorities in

determining the products value, ways of calculating duties or excise duties, obstacles to import of necessary equipment, raw materials and

components, products export, so in this context it should be noted that the reduction of customs barriers for investments enterprises requires serious goverment regulation.

UNDEVELOPMENT OF THE DOMESTIC MARKET INFRASTRUCTURE

the world practice of modern business is associated with constant cooperation with various audit, consulting and other organizations, but the absence of such companies' environment worthy, from the perspective of a foreign investor's position, significantly worsens his impression of the investment climate in the country, which in turn leads to to the absence of powerful insurance companies that would cover commercial risks during the largescale projects implementation, restrictions on long-term bank lending, the lack of high-speed transport links with industrial and commodity centres.

Fig. 2. A set of threats to the implementation of the of state influence mechanism on investments attraction by local governments Source: authors' own development 
Thus, taking into account the essence of the recommended structural elements, among which the key role to ensure the implementation of the state influence mechanism on investments attraction by local authorities in the public administration structure of the national economy play the current position of Ukraine's investment climate, the investment attractiveness dynamics, its boundaries through the securities market and methods of assessing the current level of investment security, the article substantiates the need to develop a conceptual framework for the formulation of the authors' approach in solving this issue.

In accordance with the optimization of socio-economic development of the Ukraine's regions on the basis of strengthening and activating their investment potential, an objective need to formulate a conceptual approach to understanding the essence and address the issue raises in the article, which provides that thestate influence mechanism on investments attraction by local authorities - is a set of political, legal and economic conditions that should contribute to the index dynamics of the state's investment attractiveness, the formation of which is ensured by the movement of investments in Ukraine or abroad through the stock market, because it is through its mechanisms determines the supply and demand for investment resources. Accumulation or redistribution, the analysis of which is carried out with the help of indicators, the task of which is to assess the impact degree of threats to the implementation of the state influence mechanism on investments attraction by local authorities and beyond measures to avoid and reduce the negative consequences of their actions to achieve the optimal level.

\title{
Conclusions
}

It is determined that the decisive role in the formation and implementation of the state influence mechanism on the development of regional investment policy in Ukraine belongs to the investment climate, which is a set of political, legal and economic conditions that provide and promote investment activities of domestic or foreign investors. Thus, it has been noted that the state should promote the formation of an attractive investment climate and guarantee foreign investors the inviolability of their fixed capital or the possibility of its return with a profit.

It is substantiated that among the main reasons for the unattractiveness of the Ukrainian investment climate, experts emphasize the slow pace of reforming both the national economy and the legal framework, difficult prerequisites for foreign investors to enter the regions, irrational distribution of domestic private or public investment, and unfavourable investment climate in Ukraine. the state's inability to provide financing for those economic entities that cannot be invested from private sources.

It is found out that the development and implementation of the state influence mechanism on investments attraction by local authorities in Ukraine is impossible without the next structural element as the movement of investments in the state or abroad through the stock market, because it is formed through stock market mechanisms supply or demand for investment resources, their accumulation or redistribution for economic growth are realized, ie there is a movement of capital through the circulation of various securities and their derivatives.

The measures forreducing the threats impact to the implementation of regional investment policy are systematized and implemented, that can lead not only to the deterioration of Ukraine's already not very attractive investment climate, reducing the dynamics of investment attractiveness index and investments movement in Ukraine or abroad through the securities market, and also challenge the priority areas implementation of public policy regarding the market infrastructure improvement of Ukraine's stock market, as it is one of the conceptual provisions of public administration system of the national economy.

\begin{abstract}
It is determined that the leading role in the formation and implementation of the state influence mechanism on the development of regional investment policy in Ukraine belongs to the investment climate, which is a combination of political, legal or economic conditions that ensure and facilitate the investment activities of domestic or foreign investors. Thus, it has been noted that the state should contribute to the formation of an attractive investment climate and guarantee foreign investors the inviolability of their fixed capital or the possibility of returning it with profit.

It is substantiated that among the main reasons for the unattractiveness of Ukrainian investment climate, experts name the slow pace of reforming both the national economy and the legislative framework, the difficult preconditions for foreign investors to enter the regions, the distribution of domestic private or public investments is not rational, and the unfavourable investment climate in Ukraine can be explained by the state's inability to provide financing for those business entities that cannot be invested from private sources.

It is found out that development and implementation of the state influence mechanism on the investment policy formation of regional development in Ukraine is impossible without the subsequent structural-forming element as the movement of investments into the state or beyond through the stock market, since it is through the mechanisms of the stock market that the supply or demand for investment resources is formed accumulation or redistribution for the purposes of economic growth, that is a movement of capital through the circulation of various s securities and their derivatives.

The measures for reducing the threats impact to the implementation of regional investment policy are systematized and implemented, that can lead not only to the deterioration of Ukraine's already not very attractive investment climate, reducing the dynamics of investment attractiveness index and investments movement in
\end{abstract}


Ukraine or abroad through the securities market, and also challenge the priority areas implementation of public policy regarding the market infrastructure improvement of Ukraine's stock market, as it is one of the conceptual provisions of public administration system of the national economy.

\section{References:}

1. Бодров В. Державне регулювання інвестиційного процесу в умовах кризи світових фінансових ринків: ризики і можливості / В. Бодров // Вісник Національної академії державного управління при Президентові України. - 2017. - № 4. - С. 61-67.

2. Гаврилюк О.В. Інвестиційний імідж та інвестиційна привабливість України / О.В. Гаврилюк // Фінанси України. - 2017. - № 3 (148). - С. 79-93.

3. Захаров О. Організація і управління економічною безпекою суб'єктів господарської діяльності: [навч. посіб.] / О. Захаров, П. Пригунов. - К.: Вид-во Київського національного торговельноекономічного університету, 2008. - 257 с.

4. Кириленко В.I. Інвестиційна складова економічної безпеки України: [монографія] / В. Кириленко. - К.: Вид-во Київського національного економічного університету, 2005. - 232 с.

5. Кожем'якіна С.М. Інвестиційне забезпечення розвитку економіки України / С. Кожем'якіна // Формування ринкових відносин в Україні. - 2016. - № 6 (85). - С. 37-40.

6. Кулінська А.В. Особливості формування системи індикаторів оцінки інвестиційної безпеки держави / А.В. Кулінська // Інвестиції: практика та досвід. - 2015. - № 18. - С. 11-15.

7. Кулінська А.В. Управління складовими фінансової безпеки національного господарства України: концепція та методологія: [моногр.] / А.В. Кулінська. - Одеса: ФОП Бондаренко М.О., 2016. $386 \mathrm{c.}$

8. Макарюк О.В. Напрями забезпечення фінансової безпеки України через регулювання інвестиційного ринку / О. Макарюк // Актуальні проблеми економіки. - 2017. - № 6 (96). - С. 38 42.

9. Сколотяний Ю. Антикризові стратегії для країни: державні фінанси, заощадження, інвестиції / Ю. Сколотяний, О. Дубинський // Дзеркало тижня. Україна. - 2016. - № 9 (789). - С. 3-5.

10. Федоренко В. Інвестиції та економіка / В. Федоренко // Економіка України. - 2017. - № 5. C. $12-16$.

11. Чаговець Л.О. Механізм формування стратегій стабілізації системи економічної безпеки підприємства / Л.О. Чаговець // Вісник Національного університету «Львівська політехніка». 2018. - № 628. - С. 687-691.

12. Формування стратегії безпекоорієнтованого управління інноваційно-інвестиційним кліматом регіону - с.132-163/ С.В.Філиппова, Л.О.Волощук, К.В.Ковтуненко, Ю.В.Ковтуненко. // Підрозділ п.3.1 у кол. моногр. Інноваційно-інвестиційний клімат Українського Причорномір'я: стан і безпекоорієнтований розвиток: кол. моног./ за ред.. М.М.Меркулова. - Рига, Латвія: «BaltijaPublishing». - 2019. - 308 с. - Режим доступу: https://oldiplus.ua/downloads/451.pdf . ISBN 978-9934-571-93-0.

\section{References:}

1. Bodrov V. (2017). State regulation of the investment process in a crisis of global financial markets: risks and opportunities. Visnik Natsionalnoyi akademiyi derzhavnogo upravlinnya pri Prezidentovi Ukrayini, 4, 61-67 [in Ukrainian].

2. Gavrilyuk O.V. (2017). Investment image and investment attractiveness of Ukraine. Finansi Ukrayini, 3 (148), 79-93 [in Ukrainian].

3. Zaxarov, O. \& Prygunov P. (2008). Organization and management of economic security of business entities. Kyiv: Vyd-vo Kyivkogo nacionalnogo torgovelno-ekonomichnogo universytetu [in Ukrainian].

4. Kyrylenko, V.I. (2005). Investment component of economic security of Ukraine. Kyiv: Vyd-vo Kyivkogo nacionalnogo ekonomichnogo universytetu [in Ukrainian].

5. Kozhemyakina, S.M. (2016). Investment support for the development of the Ukrainian economy. Formuvannya rynkovyx vidnosyn v Ukrayini, 6 (85), 37-40 [in Ukrainian].

6. Kulinska, A.V. (2015). Features of formation of the system of indicators of an estimation of investment security of the state. Investyciyi: praktyka ta dosvid, 18, 11-15 [in Ukrainian].

7. Kulinska, A.V. (2016). Management of Financial Security Components of the National Economy of Ukraine: Concept and Methodology. Odesa: FOP Bondarenko M.O. [in Ukrainian].

8. Makaryuk, O.V. (2017). Areas of financial security of Ukraine through regulation of the investment market. Aktualni problemy ekonomiky, 6 (96), 38-42 [in Ukrainian]. 
9. Skolotyanyj, Yu. (2016). Crisis strategies for the country: public finances, savings, investments. Dzerkalo tyzhnya. Ukrayina, 9 (789), 3-5 [in Ukrainian].

10. Fedorenko, V. (2017). Investment and economy. Ekonomika Ukrayiny, 5, 12-16 [in Ukrainian].

11. Chagovecz, L.O. (2018). The mechanism of formation of strategies for stabilization of the economic security of the enterprise. Visnyk Nacionalnogo universytetu "Lvivska politekhnika", 628, 687-691 [in Ukrainian].

12. Filippova S.V., Voloshchuk L.O., Kovtunenko K.V., Kovtunenko Y.V. (2019). Formation of a strategy of security-oriented management of innovation and investment climate of the region. Innovation and investment climate of the Ukrainian Black Sea region: state and security-oriented development: col. monologue (p.3.1). M.M. Merkulova (ed.). Riga, Latvia: BaltijaPublishing. Retrieved from https://oldiplus.ua/downloads/451.pdf. ISVN 978-9934-571-93-0.

\section{Посилання на статтю:}

Kulinska A.V. Key aspects of the state influence mechanism on investments attraction by local authorities / A.V. Kulinska, I.R. Kravtsova, O.S. Balan // Економічний журнал Одеського політехнічного університету. 2020. - № 1 (11). - C. 21-28. - Режим доступу до журн.: https://economics.opu.ua/ejopu/2020/No1/21.pdf. DOI: 10.15276/EJ.01.2020.3. DOI: 10.5281/zenodo.3975501.

\section{Reference a JournalArticle:}

Kulinska A.V. Key aspects of the state influence mechanism on investments attraction by local authorities / A.V. Kulinska, I.R. Kravtsova, O.S. Balan // Economic journal Odessa polytechnic university. - 2020. - № 1 (11). - C. 21-28. - Retrieved from https://economics.opu.ua/ejopu/2020/Nol/21.pdf.

DOI: 10.15276/EJ.01.2020.3. DOI: 10.5281/zenodo.3975501. 